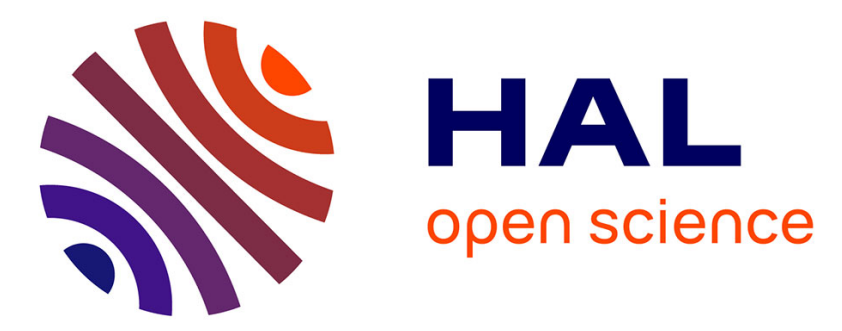

\title{
A Framework for Lean Flow in Turbulent High-Variety Low-Volume Manufacturing Environments
}

Erik Gran, Erlend Alfnes, Maria Kollberg Thomassen

\section{To cite this version:}

Erik Gran, Erlend Alfnes, Maria Kollberg Thomassen. A Framework for Lean Flow in Turbulent HighVariety Low-Volume Manufacturing Environments. IFIP International Conference on Advances in Production Management Systems (APMS), Sep 2016, Iguassu Falls, Brazil. pp.935-942, 10.1007/9783-319-51133-7_110. hal-01615811

\section{HAL Id: hal-01615811 \\ https://hal.inria.fr/hal-01615811}

Submitted on 12 Oct 2017

HAL is a multi-disciplinary open access archive for the deposit and dissemination of scientific research documents, whether they are published or not. The documents may come from teaching and research institutions in France or abroad, or from public or private research centers.
L'archive ouverte pluridisciplinaire HAL, est destinée au dépôt et à la diffusion de documents scientifiques de niveau recherche, publiés ou non, émanant des établissements d'enseignement et de recherche français ou étrangers, des laboratoires publics ou privés. 


\title{
A Framework for Lean Flow in Turbulent High-Variety Low-Volume Manufacturing Environments
}

\author{
Erlend Alfnes ${ }^{1, *}$, Maria Kollberg Thomassen ${ }^{2}$ and Erik Gran ${ }^{2}$ \\ ${ }^{1}$ Norwegian University of Science and Technology, Department of Production and Quality En- \\ gineering, Trondheim, Norway \\ erlend.alfnesentnu.no \\ ${ }^{2}$ SINTEF Technology and Society, Industrial Management, Trondheim, Norway \\ \{maria.thomassen, erik.gran\} asintef.no
}

\begin{abstract}
.
Value stream mapping (VSM) is a widely applied method for manufacturing systems design in repetitive and stable industries. A literature review of challenges and modified solutions for lean flow in high-variety low-volume (HV/LV) value streams is carried out. The solutions are categorized according to manufacturing turbulence level. The review shows that existing VSM solutions take their starting point in the original VSM principles and incorporate other relevant works only to a limited extent. Based upon the review, a coherent framework with revised VSM principles that that can be used to develop lean flow in HV/LV environments with medium and high turbulence levels is proposed.
\end{abstract}

Keywords: lean manufacturing, value stream mapping, manufacturing turbulence

\section{Introduction}

There is a need for research on extending the applicability of leanness into high variety low volume (HV/LV) environments [1]. A literature review of empirical case studies is carried out to investigate solutions of applying VSM in HV/LV environments. Many of the case studies propose modified VSM solutions to achieve a future state with lean flow in HV/LV settings, but the studies are mainly based upon the traditional VSM guidelines. They do not sufficiently build on each other to provide a more coherent set of solutions for this type of environment. The study confirms what authors such as Jina et. al [2] have observed, namely that it becomes more challenging to apply VSM as the turbulence in terms of schedule changes, mix variations, volume fluctuations, and design changes increases.

The purpose of this research is to identify principles for designing lean flows at different turbulence levels by reviewing modified VSM solutions for HV/LV in literature. The main contribution is a framework with revised VSM principles that that can be used to develop lean flow in HV/LV environments.

The paper is organised as follows. First, the methodological approach is discussed. Next, a review of challenges and modified solutions for VSM at different turbulence

adfa, p. 1, 2011.

(C) Springer-Verlag Berlin Heidelberg 2011 
levels in HV/LV case studies is carried out. The review is used to develop a VSM framework for designing lean flow at medium and high turbulence levels. Finally, conclusions are presented together with suggestions for further work.

\section{Methodological Considerations}

The objective of the literature review is to identify relevant lean principles for designing a future state map in HV/LV manufacturing environments. The reason for this choice is that VSM is a well-known and widely used lean methodology often serving as a starting point for lean implementation as it offers a way to learning to see the process or value streams [3]. A review of relevant empirical cases in literature was carried out. The cases were identified through searches in relevant databases such as Scopus and Google Scholar. We identified 14 empirical cases that met the selection criteria; the majority of the cases (10) include a current or future state value stream map, while the additional cases (4) were selected because they propose useful solutions for how to improve value streams in an HV/LV manufacturing environment. All cases propose modified lean solutions for how to map or improve manufacturing flow.

The cases are classified into low, medium and high turbulence environments based on the turbulence factors proposed by Jina et al. [2]. The VSM design principles proposed by Rother and Shook [4] are used as a reference framework to structure the case studies. The modified VSM principles that are proposed to meet major challenges are classified according to turbulence level.

\section{$3 \quad$ Literature Review}

The frame of reference is presented in this section. It includes general VSM design principles for flow manufacturing, HV/LV manufacturing and turbulence levels and a categorization of modified solutions for low, medium and high turbulence environments.

\subsection{General VSM Design Principles for Flow Manufacturing}

As part of the VSM methodology, Rother and Shook [4] defines a set of general design principles for creating flow. The principles represent rules that are to be followed and essential characteristics of a lean flow system;

- VSM is carried out for a specific product family. A family is a group of products that passes through similar processing steps and over common equipment in down stream processes.

- The production pace should be synchronized to match the pace of sales, i.e. to produce to takt time, where takt time refers to the "available production time"/"customer demand". 
- Continuous flow should be developed where it is possible, i.e. producing one piece at the time, with each item passed immediately from one process step to the next without stagnation.

- A pull system should be used to control production where continuous flow is not possible. In supermarket pull systems, Kanban trigger replenishment of what is used. If it is not practical to keep all parts in a supermarket, FIFO lanes, CONWIP, or sequenced pull might be an alternative.

- The customer schedule should be sent to a single production process. The pacemaker is the only scheduling point, and sets the pace for all upstream processes. Flow (no pull) is required downstream of the pacemaker, and it is frequently the most downstream process in the value stream. With custom products and job shops, the pacemaker often needs to be further upstream.

- The production mix and volume should be levelled. This means that the production of different products should be distributed evenly over time at the pacemaker process. Hereby a daily production rate is established that is equal to the average expected demand and to release and withdraw small consistent increments of work (pitch) at the pacemaker process.

\subsection{HV/LV and Turbulence}

HV/LV manufacturing environments include one-of-a-kind as well as small batch manufacturing environments. Manufacturing is usually make-to-order or engineer-to-order, and is normally performed in job shops [5]. A main challenge for lean implementation in $\mathrm{HV} / \mathrm{LV}$ is that they are experiencing more variability [6]. High levels of unpredictability and instability in dynamic environments make it difficult for lean operations to synchronise production processes and reduce inventory, and undermines the effectiveness of lean operations. Jina et al. [2] proposes four turbulence factors that create unpredictable and sub-optimal behaviour in manufacturing systems:

- Changes in schedule - irregular demand creates many schedule changes close to delivery due date.

- Changes in product mix - marked differences in product mix between one period and the next creates variations in workloads, especially when there is significantly different cycle time for each item.

- Volume changes - aggregate volume changes between periods over time.

- Design changes - the degree of design changes and amount of engineering work involved, and the frequency of design changes creates uncertainty and rework in manufacturing.

According to Jina et al. [2] these four types of turbulence will have a far greater impact on companies with lower manufacturing volumes than the typical lean manufacturers because the aggregated volumes in typical lean manufacturers have a beneficial dampening effect. The turbulence in HV/LV manufacturing will vary from medium to high levels. Many HV/LV manufacturers have a dominant flow in their job shops [5], and might experience less turbulence compared to the most volatile cases. Most HV/LV 
manufacturing systems do not only include jobbing, but also batch and flow manufacturing processes for components with higher volumes [7]. HV/LV manufacturers with a share of flow manufacturing processes will probably experience reduced levels of turbulence. Product features will have a large impact on turbulence. HV/LV products will vary in innovativeness and complexity [8], and can range from purely customised designs to standard designs that are kept "in stock" [9]. Standard MTO designs, with moderate complexity and innovation, can reduce turbulence to a medium level.

\subsection{Modified VSM Design Solutions}

The review of relevant case studies highlights several challenges of applying general VSM principles related to level of turbulence. In low turbulence environments, most principles seem to be easily applicable, including product family, takt time, continuous flow, pacemaker and levelling due to low variability. More challenges occur in the higher levels of turbulence.

For instance, determining a product family is a major challenge when products are produced in low volumes, high mix, are combined with customization, include multiple branches that merges and there are limited similarities between products or projects [10-13]. Due to high variety and low volumes and constantly changing projects, the traditional definition of product families may not be applicable [14, 15]. Moreover, the production of a high mix of custom and standard products, that require a lot of different parts and materials, may impose major challenges for synchronizing flows [13, 16]. Also, in situations where customer influences products that are in production, there is limited applicability of Kanban and supermarkets [15].

In order to deal with major challenges and design a lean future state, several of the investigated case studies propose modified VSM solutions. These are listed in Table 1.

Table 1. Modified solutions of investigated cases for low, medium and high turbulence levels

\begin{tabular}{lll}
\hline Principle & $\begin{array}{l}\text { Turb. } \\
\text { level }\end{array}$ & Proposed solutions \\
\hline $\begin{array}{l}\text { Product } \\
\text { family }\end{array}$ & Low & $\begin{array}{l}\text { Identify and map critical path including insertion points for other } \\
\text { branches and shared resources [17] } \\
\text { Make families of several products that have moderate differences in } \\
\text { routings and cycle times [10, 11, 13, 16, 18, 19] } \\
\text { Make families of similar projects [14] } \\
\text { Separate repetitive and handicraft projects in two families [15] }\end{array}$ \\
\hline Takt time & Medium & $\begin{array}{l}\text { Use takt rate (pcs/day) when variation is high [10] } \\
\text { Establish a set of takt modes to meet demand fluctuations [11] } \\
\text { Apply the takt time concept to the production unit as a whole and not to } \\
\text { each individual operation [19] }\end{array}$ \\
& High & $\begin{array}{l}\text { A takt time is possible to implement for runners parts with high, stable } \\
\text { demand [15] }\end{array}$ \\
\hline $\begin{array}{l}\text { Continuous } \\
\text { flow }\end{array}$ & Low & $\begin{array}{c}\text { Synchronisation between critical path and other branches through super- } \\
\text { markets and pull [17] }\end{array}$
\end{tabular}


Medium Customised and standard products are produced in the same value stream $[10,11,13]$

Customised products are only released for production when all material and engineering information is available [13]

Connect resources that are shared by several families into the flow through sequenced FIFO [11]

High Flow runners parts in focused cells with processes that are temporarily dedicated for a given duration, produce repeaters and strangers in less frequent batches within cells, in flexible job shops, or contract out to suppliers [2]

Assemble runners in lots and intersperse them with repeaters and strangers [2]

Pull system Medium Customised products are produced by customer order (directly to shipping) and standard products are produced to a finished goods super market [13]

CONWIP is applied on the production unit as a whole [13, 19]

Runners and medium volume repeaters are pulled by Kanban, low volume repeaters and strangers are controlled by sequential FIFO [16]

High Fast MRP with ability to monitor schedule changes and their impact on lower level demand. [2]

Use Kanban for parts with reasonably stable demand [2, 15]

A central supermarket and picking zone are established to provide parts to the assembly department [15]

Pacemaker Low A pacemaker is implemented at the bottleneck in the value stream [20]

Medium The whole production unit is considered as a pacemaker [10]

A pacemaker is located after the CODP [13] or at the bottleneck [12]

Levelling Low $\quad$ Work load and product mix is determined by the capacity and minimum lot size at the bottleneck [20]

Medium Daily production target defined by takt rate; mix levelling at family level only; buffering of runners as finished goods to deal with demand variability; variable lead-times quoted to customers provides additional buffering [10]

High Order sequencing with lead time and work content smoothing objectives [2]

Outsource to external suppliers if needed. Split customer orders into smaller production orders, release equal time increments of work [14]

Customer orders are split into smaller production orders (pitches) and scheduled to satisfy just-in-time delivery to the building site [15]

The few VSM case studies that propose future state maps in high turbulence environments seem to select "sheltered islands" in the manufacturing system that are separated from more unstable and varying value streams. Such units are typically producing components (such as motors or valves) that are used across many projects, and have sufficient volumes to utilise more flow-oriented manufacturing processes. They tend to have a dominant flow and a turbulence levels that make VSM more applicable. In high turbulence environments where no dominant flow or less turbulent production units can be identified, the applicability of VSM is limited. 
VSM design principles, either in a standard or modified form, becomes more applicable as turbulence in schedule, mix, volume, and design decreases. The level of turbulence is partly determined by the product features that are offered. Product features is a strategic decisions, and there can be very good reasons, such as high margins, to position the offerings in the purely customised segment. In such situations, the manufacturer will experience high turbulence and VSM becomes less applicable. The level of turbulence is also determined by the ways the order fulfilment process has been arranged and managed. By predefining the product solution space and automate some of the engineering design processes associated with the specification of a product, turbulence is reduced.

\section{A Flow Design Framework for HV/LV Manufacturing}

Based upon the review of modified VSM solutions identified in literature, a framework for HV/LV manufacturing settings is proposed, see Table 2. The review reveals that higher level of turbulence in HV/LV manufacturing makes the general lean principles more difficult to apply.

The framework includes suggestions for both high and medium turbulence settings, since HV/LV manufacturing companies may represent both turbulence levels.

Table 2. A flow design framework for HV/LV environments

\begin{tabular}{|c|c|}
\hline Category & Design principles \\
\hline Product family & $\begin{array}{l}\text { Make a family of several products with similar routings and cycle times. Map } \\
\text { the critical path in the product structure, but also include insertion points for } \\
\text { other branches and for shared resources } \\
\text { If turbulence is high, routings and cycle time can vary wildly. Make broad fam- } \\
\text { ilies of projects with some similarities in demand, geometry, level of custom- } \\
\text { isation etc. }\end{array}$ \\
\hline Takt time & $\begin{array}{l}\text { Apply takt time as = effective working time / sum of demand of all products in } \\
\text { the family during that time. Establish a set of takt modes to meet demand } \\
\text { fluctuations. } \\
\text { If turbulence is high, takt time does not make sense to control pace in daily pro- } \\
\text { duction. Use a takt rate (pcs/day or pcs/week) that is revised monthly. }\end{array}$ \\
\hline $\begin{array}{l}\text { Continuous } \\
\text { flow }\end{array}$ & $\begin{array}{l}\text { Produce customised and standard products in the same value stream and control } \\
\text { the flow through FIFO lanes. Only release customised products for produc- } \\
\text { tion when all material and engineering information is available. Connect } \\
\text { shared resources and other branches into the flow through sequenced FIFO. } \\
\text { If turbulence is high, schedule changes and design changes happens, and nu- } \\
\text { merous routings and cycle times are possible. Keep all products in the same } \\
\text { value stream, or establish value streams based on broad project families in } \\
\text { order create a "quasi-continuous" flow and a reduction of disturbances. If no } \\
\text { takt is feasible, control the flow through CONWIP. }\end{array}$ \\
\hline Pull system & $\begin{array}{l}\text { Produce customised products to customer order (directly to shipping) and pull } \\
\text { standard products to a finished goods supermarket. Parts that are runners and } \\
\text { medium volume repeaters are pulled into the main flow by Kanban, control } \\
\text { low volume repeaters and strangers by sequential FIFO lanes. }\end{array}$ \\
\hline
\end{tabular}


If turbulence is high, the applicability of Kanban and supermarkets is limited to some standard runners parts.

Pacemaker The pacemaker has a backlog of productions orders, and release them in a takt to control the pace of the value stream. With custom products and job shops, the pacemaker often needs to be upstream. Locate a pacemaker after the CODP and/or at the bottleneck.

If turbulence is high, no single pacemaker can be identified. Use the whole value stream as a pacemaker.

Levelling Define daily production target by takt time, level mix at family level only, and use buffer of runners as finished goods to deal with demand variability. Use variable lead-times quoted to customers provides additional buffering.

If turbulence is high, try to cope with schedule changes, design changes, and demand fluctuations trough order sequencing with lead time and work content smoothing objectives. Ramp up capacity if needed. Extreme load peaks are outsourced to external suppliers.

\section{Conclusion}

This paper analyses cases where VSM is applied in manufacturing environments that are relevant for $\mathrm{HV} / \mathrm{LV}$. The cases are classified according to turbulence level. A framework for flow design in HV/LV manufacturing is proposed. The review shows that the standard VSM design principles are easily applicable in low turbulence settings, and that modified versions of VSM are less problematic in medium turbulence environments compared to high turbulence environments.

The major contribution includes an overview of existing modified VSM design principles for HV/LV settings. Detailed insights to modified solutions for different turbulence levels are provided. The framework of modified VSM design principles may serve as a starting point for the development of practical guidelines in HV/LV environments. Manufacturers, especially with medium turbulence, may use the framework to establish flow. Manufacturers in highly turbulent environments should seek to reduce the level of turbulence to ensure efficient application of the modified VSM design principles.

The framework should be further refined by testing modified design principles in one or several case companies representing environments of different turbulence levels.

Acknowledgements. This research is supported by the Research Council of Norway through the research projects EFFEKT and Manufacturing Network 4.0.

\section{References}

1. Papadopoulou, T., Özbayrak M.: Leanness: experiences from the journey to Date. Journal of Manufacturing Technology Management, 16(7), 784-807 (2005)

2. Jina, J., A.K. Bhattacharya, Walton, A.D. Applying Lean Principles for High Product Variety and Low Volumes: Some Issues and Propositions. Logistics Information Management, 10(1), 5-13 (1997) 
3. Rivera, L. and F.F. Chen, Measuring The Impact of Lean Tools on the Cost-Time Investment of a Product Using Cost-Time Profiles. Robotics and Computer-Integrated Manufacturing, 23(6), 684-689 (2007)

4. Rother, M., Shook, J.: Learning to See: Value Stream Mapping to Add Value and Eliminate Muda. Lean Enterprise Institute (2003)

5. Portioli-Staudacher, A., Tantardini, M. A Lean-Based ORR System for Non-repetitive Manufacturing. International Journal of Production Research, 50(12), 3257-3273 (2012)

6. Hines, P., Holweg, M., Rich, N.: Learning to Evolve: A Review of Contemporary Lean Thinking. International Journal of Operations \& Production Management, 24(10), $994-$ $1011(2004)$

7. Hicks, C., McGovern, T. Earl, C.F.: A Typology of UK Engineer-to-order Companies. International Journal of Logistics, 4(1), 43-56 (2001)

8. Cigolini, R., Pero, M., Sianesi, A.: When ETO Companies Design the Supply Chain During New Product Development Process. International Journal of Engineering, Science and Technology, 6(3), 30-41 (2014)

9. Wikner, J., Rudberg, M.: Integrating Production and Engineering Perspectives on the Customer Order Decoupling Point. International Journal of Operations \& Production Management, 25(7), 623-641 (2005)

10. Lander, E., Liker,and J.K.: The Toyota Production System and Art: Making Highly Customized and Creative Products the Toyota Way. International Journal of Production Research, 45(16), 3681-3698 (2007)

11. Duggan, K.J.: Creating Mixed Model Value Streams: Practical Lean Techniques for Building to Demand. 2013, Boca Raton, Fla.: Taylor \& Francis. XX, 238 s. 12.

12. Stamm, M., Neitzert, T.: Value Stream Mapping (VSM) in a Manufacture-To-Order Small and Medium Enterprise (2008)

13. McDonald, T., Van Aken, E.M., Rentes, A.F.: Utilising Simulation to Enhance Value Stream Mapping: A Manufacturing Case Application. International Journal of Logistics, 5(2), 213-232 (2002).

14. Matt, D.: Adaptation of the Value Stream Mapping Approach to the Design of Lean Engineer-To-Order Production Systems: A Case Study. Journal of Manufacturing Technology Management, 2014. 25(3): p. 334-350.

15. Matt, D.T., Rauch, E.: Implementing Lean In Engineer-To-Order Manufacturing: Experiences from. Handbook of Research on Design and Management of Lean Production Systems (2014)

16. Horbal, R., Kagan, R., Koch, T.: Implementing lean manufacturing in high-mix production environment, in Lean Business Systems and Beyond. Springer (2008)

17. Braglia, M., Carmignani, G. Zammori, F.: A New Value Stream Mapping Approach For Complex Production Systems. International Journal of Production Research, 44(18-19), 3929-3952 (2006)

18. Bertolini, M., Romagnoli, G.: Lean Manufacturing in the Valve Pre-Assembly Area of a Bottling Lines Production Plant: An Italian Case Study. In Proceedings of 2013 International Conference in Industrial Engineering and Systems Management (2013)

19. Bokhorst, J.A., Slomp, J. : Lean Production Control At A High-Variety, Low-Volume Parts Manufacturer. Interfaces, 40(4), 303-312 (2010)

20. Serrano, I., Castro, R., Goienetxea, A.: Pacemaker, Bottleneck and Order Decoupling Point in Lean Production Systems. International Journal of Industrial Engineering: Theory, Applications and Practice, 16(4) (2009) 